https://doi.org/10.3727/152599519X15506259856110

MS 18018 accepted for publication in Event Management

\title{
MOTIVATION AND PSYCHOLOGICAL CONTRACT IN SPORT EVENT \\ VOLUNTEERISM: THE IMPACT OF CONTRACT FULFILMENT ON \\ SATISFACTION AND FUTURE BEHAVIORAL INTENTION
}

\section{Corresponding author: Eunjung Kim, PhD., Lecturer}

Sport, Event, Tourism and Hospitality, School of Business and Law, Edith Cowan University, 270 Joondalup Drive, Building 2 Room 250, Joondalup WA 6027, Australia

Phone: +61 86304 5138; Email: e.kim@ecu.edu.au

\section{Graham Cuskelly, PhD., Professor}

Department of Tourism, Sport and Hotel Management, Griffith Business School, Business G 27, Parklands Drive, Griffith University, Gold Coast Campus, Southport, Queensland 4222,

Australia; Email: g.cuskelly@griffith.edu.au

\section{Liz Fredline, PhD., Senior Lecturer}

Department of Tourism, Sport and Hotel Management, Griffith Business School, Business G 27, Parklands Drive, Griffith University, Gold Coast Campus, Southport, Queensland 4222, Australia; Email: 1.fredline@griffith.edu.au 


\begin{abstract}
This study investigated sport event volunteer motivation and psychological contract (PC) with regard to the relationship between PC fulfilment, satisfaction and future behavioral intention. Motivation-based volunteer sub-groups based on cluster analysis were compared regarding their expectations and experiences of PC types as well as their overall satisfaction and future behavioral intention in a pre and post-test study. The gap between expectations and experiences of PC types (PC fulfilment by gap: PCFg), and second, experience (satisfaction) of PC types (PC fulfilment by experience: PCFe) were tested using regression analysis to investigate the impact of PC fulfilment on satisfaction and future behavioral intention. The analysis was conducted on a sample of 261 sport event volunteers from three sport events in south east Queensland, Australia. Amongst this volunteer sample, ideological PC was considered as the most important PC type overall, but different motivations were associated with different PC preferences. Volunteers who had different motivations had varying experiences of PC types, overall satisfaction and intention to continue volunteering. PCFe was highly related to overall satisfaction and future behavioral intention and was found to be a better predictor of volunteer satisfaction than PCFg, This study provides important theoretical and practical implications for sport event volunteerism approached from the perspective of PC types and motivations.

Keywords: Psychological contract theory, Volunteer motivation, Volunteer satisfaction, Volunteer management, Sport events
\end{abstract}




\section{MOTIVATION AND PSYCHOLOGICAL CONTRACT IN SPORT EVENT \\ VOLUNTEERISM: THE IMPACT OF CONTRACT FULFILMENT ON \\ SATISFACTION AND FUTURE BEHAVIORAL INTENTION \\ INTRODUCTION}

Many sectors of society have derived benefits from the support of volunteers. Sport events in particular have relied greatly on volunteers who constitute a major human resource to successfully deliver sport events. Sport events are typically dependent on episodic volunteers who participate in more flexible, short-term and once-off volunteering (Holmes \& Smith, 2009) and such volunteers provide event managers with the capacity to enhance and expand the quantity and diversity of services within the constraints oflimited budgets.

According to the International Labor Organization (2011), volunteer activities can be most effective if volunteers are well managed. Ás volunteers comprise a large proportion of the overall staffing in many events (Pauline \& Pauline, 2009), volunteers and organizers should function as a team with detailed responsibilities and duties. This teamwork is essential for hosting successful sport events. Therefore, it is important to build and maintain good relationships between yolunteers and event organizers in order to effectively manage volunteers.

The need to develop effective volunteer management strategies has led to an interest in applying the concept of psychological contract (PC) (Nichols \& Ojala, 2009). PC is a cognitive, subjective and interpretative state and explains the development and maintenance of the relationship between an individual and an organization. The study of PC plays a purposeful role in understanding the contribution of volunteers (Farmer \& Fedor, 1999). Also, an understanding of the motivations and characteristics of volunteer groups and sub-groups is important to 
determine the most suitable volunteer management strategies (Alexander, Kim, \& Kim, 2015;

Schlesinger \& Gubler, 2016).

Although volunteer management in sport events has emerged as an increasingly important area of research endeavor (Farrell, Johnston, \& Twynam, 1998; Nichols \& Ojala, 2009; Wang \& Yu, 2015), there is a lack of research on the analysis and impact of motivation and PC in sport event volunteerism. Therefore, this research proposes the following research questions:

RQ 1. What is the most important PC type?

RQ 2. Do volunteers who have different motivations value different PC types?

RQ 3. What are the level of experiences of PC types, oyerall satisfaction, and future behavior intention between motivation-based volunteer sub-groups?

RQ 4. Is the PC fulfilment by gap (PCFg) positively associated with overall satisfaction and future behavioral intention?

RQ 5. Is the PC fulfilment by experience (PCFe) positively related to overall satisfaction and future behavioral intention?

To investigate these research questions, this study segments sport event volunteers on the basis of their motivation. These motivation-based volunteer sub-groups are compared regarding expectations and experiences of PC types as well as overall satisfaction and intention to continue volunteering. PC fulfilment is examined to explore the impact on satisfaction and future behavioral intention. Figure 1 displays the conceptual framework for the design of this study (see Figure 1).

$<<$ Insert Figure 1 Here $>>>$ 


\section{LITERATURE REVIEW}

This section discusses PC theory and how this theory and the concepts of PC have been applied in volunteer research. As this study categorizes sport event volunteers based on motivation, a volunteer motivation scale is described in this literature review to identify different kinds of volunteer motivations.

\section{Psychological Contract Theory}

PC has been defined by several researchers (e.g. Argyris, 1960; Levinson, 1962; Schein, 1980) to identify the subjective nature of employment relationships and is based on social exchange theory. The contemporary concept of PC was guided mainly by the work of Rousseau (1989) who defined PC as "individual beliefs, shaped by the organization, regarding terms of an exchange agreement between individuals and their organization" (Rousseau, 1995, p.9). PC involves beliefs about what employees are expecting to receive, because they believe that their employer made promises to provide those things.

Rousseau (1989) distinguished between transactional and relational PC types.

Transactional PC focused on the exchange of economic currency which was perceptions of promised tangible and material inducements within a well-defined and short-term time frame (Rousseau, 1990), Relational PC focused on the perceived exchange of socio-emotional currency which was based on mutual trust and was subjective in nature within an unclearly defined and long-term time frame (Rousseau, 1990). Research by Thompson and Bunderson (2003, p. 574) added ideological PC defined as "credible commitments to pursue a valued cause or principle (not limited to self-interest) that are implicitly exchanged at the nexus of the individual organization relationship". Hence, ideological PC focused on the exchange of ideological currency which was expressed in the mission, values, or principles of an organization. Thompson 
and Bunderson (2003) argued that volunteers perceiving obligations to contribute to the goals of an organization could explain the ideological PC type.

An increasing interest in PC studies has been focused on the effects of PC breach and fulfilment (e.g. Farmer \& Fedor, 1999; Grimmer \& Oddy, 2007; Robinson, 1996; Robinson \& Rousseau, 1994; Starnes, 2007; Vantilborgh, Bidee, Pepermans, Willems, Huybrechts \& Jegers, 2014). The breach or fulfilment of PC influences individuals' attitude and behavior towards an organization (Conway \& Briner, 2005). Morrison and Robinson (1997) argued that PC breach had two dimensions; reneging and incongruence. Reneging occurred "when agents of the organization recognize that an obligation exists, but they knowingly fail to follow through on that obligation" (Morrison \& Robinson, 1997, p. 233). Incongruence occurred "when an employee has perceptions of a given promise that differ from those held by the organizational agent or agents responsible for fulfilling that promise" (Morrison \& Robinson, 1997, p. 235).

In contrast, PC fulfilment was concerned with increased trust and affective organizational commitment (Ali, Haq, Ramay \& Azeem, 2010; Kingshott \& Pecotich, 2007). Coyle-Shapiro and Kessler (2003) argued that the obligation fulfilment of an organization leads to higher levels of commitment. Several studies investigating PC have reported a negative influence of PC breach and a positive impact of PC fulfilment in terms of personal outcomes such as job satisfaction, organizational commitment and intention to continue (e.g. Bunderson, 2001; CoyleShapiro \& Kessler, 2003; Withey \& Cooper, 1989). The impacts of PC fulfilment and breach seem to be important in managing volunteers as this outcome from those effects is of primary concern for the organizations looking to enhance volunteers' performance (Bussell \& Forbes, 2002). Therefore, being aware of fulfilling PC can contribute to more effective volunteer 
management and may improve volunteers' satisfaction and intentions to volunteer again in the future.

Although PC fulfilment and breach have been explored by several studies (e.g. Griep, Vantilborgh, Baillien \& Pepermans, 2016; Harman \& Doherty, 2017; Rayton \& Yalabik, 2014; Vantilborgh, 2015; Vantilborgh et al., 2014; Walker, Accadia \& Costa, 2016), clear conceptualization and measurement of PC fulfilment and breach has not yet occurred. Therefore, this current study conceptualizes and measures PC fulfilment in two ways. PC fulfilment is measured both as the gap between expectations and experiences (PCFg) and as the satisfaction of experiences of $\mathrm{PC}(\mathrm{PCFe})$. By comparing the results in the two approaches, $\mathrm{PC}$ fulfilment can be explored to better explain the impact of PC fulfilment on satisfaction and future behavioral intention.

\section{Application of Psychological Contract Theory to Volunteerism}

Application of the concept of PC, types to the recruitment and management of volunteers may predict volunteer satisfaction and future intentions to volunteer. PC not only develops but also sustains a relationship between an organization and a volunteer over time (Taylor, Darcy, Hoye, \& Cuskelly, 2006). In this sense, the application of PC theory can help to identify important factors that underpin and facilitate good relationships and teamwork between event organizations and volunteers.

There has been extensive research involving PC in mainstream management (e.g. Karagonlar, Eisenberger, \& Aselage, 2016; Low, Bordia, \& Bordia, 2016; Lu, Capezio, Restubog, Garcia, \& Wang, 2016; Robinson \& Rousseau, 1994). However, the unique characteristics of volunteers suggest that there are several differences between mainstream management and volunteer management with regard to how individuals perceive PC. First, it is 
the matter of monetary remuneration. By definition, because volunteers are not paid a wage they are more likely to expect more in terms of relational PC (Kim, Trail, Lim, \& Kim, 2009) rather than transactional PC (Taylor et al., 2006). Relational PC is an agreement in terms of a social relationship which can be an important motive for volunteers (Bang, Won, \& Kim, 2009;

Schlesinger \& Gubler, 2016). Volunteers are concerned with the nonmonetary benefits that they receive from volunteering. With regard to these benefits, volunteers may have expectations of relational PC in specific areas such as social interactions and career-related benefits (Kim et al. 2009). Second, since volunteers tend to have greater freedom than paid employees in choosing types of tasks and organizations, they may perceive different kinds of mutual obligations (Farmer \& Fedor, 1999). Such different obligations may mean that fulfilment of PC of volunteers is more likely to be influenced by their willingness, perceptions and intention in regard to volunteering rather than by other circumstances.

By identifying the differences between maínstream management and volunteer management, this study clarifies the differences in expectations of PC types in volunteer management practices. For example, some volunteers may expect to receive reimbursement for expenses made and material support for performing their tasks and fulfilling basic role requirements (Vantilborgh, Bidee, Pepermans, Willems, Huybrechts \& Jegers, 2012) such as being provided with uniforms, free tickets, food and other tangible benefits. Other volunteers may expect to become well-integrated within the group, receive recognition for completed work and have sufficient autonomy in undertaking their volunteer activities (Vantilborgh et al., 2012). Alternatively, volunteers may perceive that an organization promises to devote time and effort to achieve its mission (Vantilborgh, Bidee, Pepermans, Willems, Huybrechts \& Jegers, 2013). 
Volunteers are therefore willing to participate and contribute to the values and mission of the organization.

PC theory has been applied to volunteerism but in a limited number of studies and not extensively in the context of sport events (e.g. Farmer \& Fedor, 1999; Liao-Troth, 2005; Nichols \& Ojala, 2009; Taylor et al., 2006; Vantilborgh et al., 2012, 2013, 2014; Wang \& Yu, 2015). Nichols and Ojala (2009) and Vantilborgh et al. (2012) conducted qualitative research to provide an overview of PC that was applied to volunteerism. Nichols and Ojala (2009) identified the expectations of event managers and sport event volunteers. Event managers were primarily concerned with reliability. In contrast, sport event volunteers focused on expectations in relation to flexibility of engagement, the quality of personal relationships, recognition for their contribution and clear communication. Vantilborgh et al. (2012) identified a value-based PC type as well as transactional and relational PC types. The value-based PC type could be interpreted as ideological PC. Vantilborgh et al. (2012) argued that the value-based PC type was related to the mission and values of the organization reported by volunteers and this PC type might be crucial for increasing the involvement of volunteers.

Studies by Farmer and Fedor (1999) and Vantilborgh et al. (2014) examined the effect of PC fulfilment and breach amongst volunteers. Farmer and Fedor (1999) found that the level of perceived support from an organization significantly increased the commitment of volunteers in various events and reduced withdrawal or turnover intentions. They reported a positive relationship between organizational support and volunteer participation. Vantilborgh et al. (2014) reflected on the lack of research regarding ideological PC breach and fulfilment, even though this PC type has distinct influences on outcomes such as the improvement of volunteers' work effort. They investigated how ideological PC breach and fulfilment influenced the work effort of 
volunteers and found that fulfilling ideological obligations seemed like a signal that volunteers care about the mission, values, and principles of organizations. Vantilborgh et al. (2014) found that work effort increased in situations of either low or high fulfilment of ideological PC. In the case of ideological PC breach, they suggested that if ideological PC under-fulfilment becomes too large or is prolonged for an extended period of time, volunteers may make a decision to change their preferred PC or to leave the exchange agreement.

Research by Liao-Troth (2005), and Wang and Yu (2015) considered volunteer motivation and PC. Liao-Troth (2005) examined how PC, volunteer motivation, and personality were related to each other in two studies. The only significant result was a relationship between a career motive and transactional PC. Liao-Troth concluded that volunteer motives did not have a direct effect on PC types. However, Liao-Troth argued that it would be incorrect to dismiss the effects of motives on PC as motives might influence the content of PC perceived by volunteers. There were several limitations in Liao-Troth's study. First, the findings may not be generalized to other volunteer populations. Even though both samples in two studies were in volunteer situations (firefighters and students), these were not similar enough to make generalizations about volunteers overall. Second, Liao-Troth's study did not consider the ideological PC type. Liao-Troth explored only transactional and relational PC types.

Wang and $\mathrm{Yu}_{\mathrm{u}}(2015)$ tested a conceptual model of sustained volunteerism using motivation and PC as predictors. Their study found that extrinsic reward had a negative effect on satisfaction for students to volunteer at an Expo event. Their findings showed that perceived PC was positively associated with volunteer satisfaction and such volunteer satisfaction led to increased intentions to volunteer in the future. They argued that motivation and PC had a direct effect on volunteer satisfaction and sustained volunteerism. However, several limitations were 
noted in Wang and Yu's study. First, their study identified PC as a single concept rather than three PC types. Second, their study explored prosocial beliefs and behaviors of student volunteers in the context of a mega event, and therefore, the findings may not be generalizable to other types of events not least because study was limited to a relatively homogeneous group of college students with data collection from a single Expo event.

Cognizant of the limitations of previous studies, the current study attempts to improve generalizability by investigating volunteers drawn from three different sport events. This study aims to categorize sport event volunteers based on their motivation. Comparisons are made between motivation-based volunteer sub-groups in relation to their expectations and experiences of the three PC types as well as overall satisfaction and intention to continue volunteering. This study also focuses on PC fulfilment to better understand the impact of PC fulfilment for predicting volunteer satisfaction and future behavioral intention.

\section{Volunteer Motivation}

Several studies have investigated volunteer motivation and developed scales aimed at identifying the range of factors which motivate people to volunteer in a variety of situations. These include the volunteer function inventory (VFI) (Clary, Snyder, Ridge, Copeland, Stukas, Haugen \& Miene, 1998), the special event volunteer motivation scale (SEVMS) (Farrell et al., 1998) and the volunteer motivation scale for international sporting events (VMS-ISE) (Bang et al., 2009). The VFI and the SEVMS have identified key factors of volunteer motivation and have been applied more frequently than the VMS-ISE. However, in order to fully understand the motivations of sport event volunteers, a scale developed for the sport context was considered more appropriate (Kim, Fredline, \& Cuskelly, 2018). In this regard, Bang et al. (2009) investigated whether volunteers were willing to contribute to communities and sport events in 
order to host a successful sport event. Bang et al. (2009) developed the seven factor VMS-ISE scale which included the following dimensions: (1) expression of values, related to altruistic values for other people; (2) community involvement, feeling a sense of belonging, pride and community spirit; (3) interpersonal contacts, focusing on friendship and social network; (4) career orientation, preparing for the career and gaining career-relevant experiences; (5) personal growth, increasing self-worth and self-esteem; (6) extrinsic rewards, related to tangible benefits such as free admission, uniform and food; and (7) love of sport, loving the sport and liking any event of the sport. The love of sport factor can be regarded as an incentive, especially for sport event volunteers who are willing to spend their time and effort for sport events. They want to enjoy sports and express their love for being engaged in activities associated with sport. In this sense, the VMS-ISE confirmed the attractiveness of sport itself as a motive unique to sport event volunteers. The current study therefore used the scale developed by Bang et al. (2009) because of the love of sport dimension and community inyolyement dimension in the VMS-ISE scale.

\section{METHODS}

The methods section explains how the study was conducted, which data were collected and how the data were analyzed. This section includes: (1) sampling frame; (2) instruments; (3) data collection and procedures; and, (4) treatment and analysis of data. This study developed two surveys (i.e. pre-event survey and post-event survey) and collected data from three different annual sport events. Ethical clearance was approved by the University Human Research Ethics Committee before data collection began.

\section{Sampling Frame}

This study builds on the research reported in Kim et al. (2018) that segmented sport event volunteers by motivation using an hierarchical cluster analysis technique. The samples in that 
study came from three events; the 2015 Australian PGA Championship Gold Coast (Golf tournament event), the 2016 Gold Coast Airport Marathon (Running event) and the 2016 Cycle Queensland (Cycling event). Following data collection at the 2015 PGA event, some modifications were made to the instruments in the items collecting PC data. Therefore, the sample analyzed in this study comprises volunteer surveys collected at the 2016 Marathon event, the 2016 Cycle Queensland event and the 2016 PGA event.

In an effort to establish a basis for pooling the response data from three different sport events, the bivariate correlation matrices for each event were visually observed and compared for similarity. Comparable patterns were identified. Afterward, the pooled correlation matrix was inspected for intercorrelations. All statements were found to be correlated significantly $(r>0.4)$ with at least two other items. It was therefore determined that the pooled data set was suitable for analysis.

A total of 578 (i.e. Marathon: $n=195$ Cycling: $n=123$ and PGA: $n=260$ ) volunteers were invited to participate in the study and a useable sample for the analysis (with both pre-event and post-event surveys completed) involved 261 responses (i.e. Marathon: $n=104$, Cycling: $n=53$ and PGA: $n=104)$. The effective response rate was therefore $45.1 \%$ taking into account respondents who provided useable data by completing both pre and post-event surveys.

\section{Instruments}

As mentioned, this study conducted a pre-event survey and a post-event survey. There were several variables collected in each of the two surveys and these variables were conceptualized in context with this study as summarized in Table 1.

\section{$<<<$ Insert Table 1 Here $>>>$}


The pre-event instrument included four parts: (1) motivations of volunteers, (2) expectations in relation to PC types, (3) ranking of PC types and (4) socio-demographic information. The motivation items used for this study were adapted from Bang et al.'s study (2009) that identified seven factors of volunteer motivation in a sport event context. The items in terms of PC were developed to specify three types of PC (i.e. transactional, relational and ideological). Three statements addressing PC types evaluated the expectations of volunteers regarding each PC type. These three statements were also ranked by the perceived importance of three PC types. Five questions addressing socio-demographic information were also included (e.g. gender, age, marital status, employment status, and educational level).

The post-event instrument contained three parts: (1) volunteer self-reported experiences in relation to the $\mathrm{PC}$ types, (2) overall satisfaction in working with the sport event organization and (3) intention to continue volunteering. The level of satisfaction of experiences regarding PC types was rated on a 5-point Likert scale and indicated PC fulfilment experience score (PCFe). The experience items regarding PC types corresponded with the expectation items to enable post-event experiences to be compared with pre-event expectations. The gap between expectations and experiences of PC types determined PC fulfilment gap score (PCFg). Finally, the post-event questionnaire asked whether respondents were satisfied with their overall volunteer experiences at the sport event and whether they intended to volunteer at the event next year.

\section{Data Collection and Procedures}

Volunteers were invited either in person or via email to complete the two surveys. A preevent survey invitation was firstly emailed to registered volunteers at the three events using the database of volunteers registered for these events one or two weeks before the start of each 
event. The invitation to participate in the survey was conveyed via event volunteer coordinators as a condition of ethics approval which was to guarantee anonymity of survey participants. Four days later registered volunteers received a reminder email in order to encourage a high response rate. Volunteers who were not able to respond to the online pre-event survey were asked to complete the hard copy of the pre-event survey during the early stages of each event. At the end of each event, the hard copy of the post-event survey was handed to volunteers who expressed a preference to complete the post-event survey onsite. A post-event survey invitation email was sent to the other volunteers by event volunteer coordinators in the three events one or two weeks after the end of each event which was followed by a reminder four days later.

The participation of respondents in this research was completely voluntary and their responses were anonymous. No identifying information was used in reports of the findings. Only the 'code' allowed the researcher to match their pre-event survey responses to their post-event survey responses without identifying them. The ‘code' was made up of last letter of first name, last letter of family/surname, day of birthday and month of birthday. Respondents were requested to enter their 'code' in the survey questionnaire. If the respondents changed their mind after initially participating, they were free to withdraw from the study at any time without comment or penalty.

Both pre- and post-event online surveys administered in this research used a forced response option and both pre- and post-event onsite surveys were completed under the direction of the researcher to let respondents answer all questions. Surveys returned incomplete (i.e. included missing data), were excluded from all analyses. The completed pre- and post-event survey data were only used for the analysis when the pre-event survey responses were able to match to the post-event survey responses. Where respondents completed the pre-event survey but 
did not complete the post-event survey, both the pre-event and post-event survey data were excluded from the analyses.

\section{Treatment and Analysis of Data}

SPSS version 22 was used to code and analyze data collected from the volunteers at each of the three events. First, an exploratory factor analysis (EFA) was conducted using Principal Component Analysis with varimax rotation to identify the factors underlying the set of items with regard to motivation. This analysis was for descriptive purposes to facilitate understanding of the subsequent cluster analysis.

Second, a hierarchical cluster analysis on standardized raw data variables was used to segment sport event volunteers by their motivations. Each cluster was then described on the basis of their scores on the motivation factors identified in the EFA. Raw scores were used in the cluster analysis rather than factor scores as this approach is more likely to determine the best cluster solution because original information in the dataset is mostly retained (Dolnicar \& Grün, 2008). Chi-square tests were then used to identify any significant relationships between sociodemographic information and the motivation-based volunteer clusters identified.

Third, the differences between motivation-based volunteer sub-groups in terms of expectations and experiences of three PC types as well as overall satisfaction and intention to continue volunteering were tested using an ANOVA procedure with Scheffe post-hoc tests. Paired t-tests were conducted on the paired items of the three PC types (expectations and experiences) to investigate the gaps in terms of PC types as perceived by the volunteers. Given several cases of comparisons being made, a conservative alpha level was used $(\alpha=0.017,0.05 / 3$; $\alpha=0.025,0.05 / 2)$ to maintain an acceptable family-wise type I error rate. This Bonferroni-type 
correction was used to reduce the chances of obtaining type I errors. The differences that are significant at the 0.05 level are indicated for the interest of readers.

Fourth, correlation and regression analysis were used to investigate the relationship between overall satisfaction and PC fulfilment (PCFg and PCFe), and to identify the impact of PC fulfilment on overall satisfaction and intention to continue volunteering.

\section{RESULTS}

The results are presented in four parts: (1) volunteer categorization based on motivations; (2) PC types between motivation-based volunteer sub-groups; (3) experiences of PC types, overall satisfaction and future behavioral intention between motivation-based volunteer subgroups; and (4) impact of PC fulfilment on volunteer satisfaction and future behavioral intention.

\section{Volunteer Categorization Based on Motivations}

Of the 21 items included in the pre-event survey instrument, five motivation factors were identified from 16 items. Due to high cross-loadings between factors, two items (i.e. 'volunteering makes me feel needed' and 'volunteering makes me feel important') were omitted. Also, three items (i.e. 'I want to interact with others', 'I want to develop relationships with others' and 'I want to work with different people') were omitted as these items loaded on the wrong factor. Due to omission of these five items which related to the VMS-ISE personal growth and interpersonal contacts factors, a total of five volunteer motivation factors were eventually identified and labelled (1) expression of values, (2) career orientation, (3) community involvement, (4) love of sport, and (5) extrinsic rewards.

After conducting an hierarchical cluster analysis using the same procedure as Kim et al. (2018), the data ( $\mathrm{n}=261$ ) were summarized in a four cluster solution and then described based on the factor scores of the five motivation factors identified in the EFA (see Table 2). Group 1 had 
the largest proportion of volunteers ( $\mathrm{n}=118 ; 45.2 \%$ of cases) and had high and positive mean scores for the factors of community involvement (0.58) and love of sport (0.32), so it was named as 'sport and community enthusiasts'. Group 2 was the second largest group including 81 volunteers (31.0\% of cases) and was highest on the factor expression of values $(0.02)$, and therefore it was labelled as 'altruists'. Group 3 was the smallest group involving 28 volunteers $(10.7 \%)$ and their average mean score for the extrinsic rewards factor (0.64) was substantially higher compared to other groups. It was therefore named 'material benefits seekers'. Group 4 accounted for 34 out of 261 volunteers (13.0\% of cases) and had high and positive mean scores on the factors of career orientation (1.39) and community involvement (0.75), therefore, it was labelled as 'career and community-oriented people'. These results were highly similar to the segmentation of sport event volunteers reported in Kim et al. (2018).

$$
<<<\text { Insert Table } 2 \text { Here }>>>
$$

\section{PC Types Between Motivation-Based Volunteer Sub-Groups}

With regard to RQ1, volunteers examined in this study tended to rate $(m=3.7)$ ideological PC as the most important PC type rather than transactional $(\mathrm{m}=3.20)$ and relational PC types $(\mathrm{m}=3.43)$ (see Table 3). Nearly half $(44.4 \%)$ of the volunteers ranked ideological PC as the most important. 'Career and community-oriented people' placed significantly more importance on expectations of ideological PC $(\mathrm{m}=4.12)$ compared to 'altruists' $(\mathrm{m}=3.48)$ and 'material benefits seekers' $(m=3.39)$. In contrast, 'material benefits seekers' had a higher mean score on expectations of transactional PC $(\mathrm{m}=3.61)$ compared to 'altruists' $(\mathrm{m}=2.86)$. Amongst 'material benefits seekers', $64.3 \%$ ranked transactional PC as the most important as these volunteers preferred tangible benefits rather than intangible benefits or values. Therefore, in relation to 
RQ2, there is evidence that volunteer sub-groups that were motivated by different dominant motivations seemed to value different PC types.

\section{$<<<$ Insert Table 3 Here $>>>$}

\section{Experiences of PC Types, Overall Satisfaction and Future Behavioral Intention Between}

\section{Motivation-Based Volunteer Sub-Groups}

With respect to RQ3, in the case of experiences of the three PC types, the highest level of satisfaction was associated with ideological PC $(\mathrm{m}=4.11)$ and this was consistent across all of the motivation-based volunteer sub-groups (see Table 4). 'Career and community-oriented people' were particularly satisfied with all PC types in comparison with other volunteer sub-groups. In contrast, the lowest level of overall satisfaction was with regard to transactional PC $(\mathrm{m}=3.94)$. In particular, 'material benefits seekers' were less satisfied with three PC types than other volunteer sub-groups.

In the case of overall satisfaction and future behavioral intention, the mean scores of the entire volunteer group indicated a high level of overall satisfaction $(\mathrm{m}=4.07)$ and positive agreement with the intention to continue volunteering next year $(\mathrm{m}=3.88)$ (see Table 4). By comparing the differences in means of overall satisfaction and intention to continue volunteering between the four motivation-based volunteer sub-groups, this current study identified that 'career and community-oriented people' were more highly satisfied with working in the sport event than other groups. In contrast, 'material benefits seekers' were less likely to be generally satisfied with their volunteer activities and continue to volunteer next year. Therefore, volunteers who had the highest level of satisfaction on experiences of each PC type tended to have the highest level of overall satisfaction and intention to continue volunteering.

$<<<$ Insert Table 4 Here $>>>$ 


\section{Impact of PC Fulfilment on Volunteer Satisfaction and Future Behavioral Intention}

As mentioned in section 2, the concept of PC fulfilment has been discussed in the literature but not clearly operationalized. Therefore, this study measured PC fulfilment in two ways (PCFg and PCFe) and compared the results of analysis between PCFg and PCFe, to provide a better explanation of PC fulfilment and explore its relationship with overall satisfaction.

With regard to RQ 4, the gap in mean scores between expectations and experiences of PC types was investigated (PCFg) (see Table 5). The majority at the sample had positive gap scores and therefore experienced PC fulfilment. For transactional PC, 86.2\% of volunteers in this study were fulfilled. Relational PC fulfilled $86.6 \%$ of volunteers and $83.5 \%$ of volunteers were fulfilled for ideological PC. Overall, experiences exceeded expectations, therefore it could be concluded that PC fulfilment has occurred for the majority of volunteers sampled.

\section{$<<<$ Insert Table 5 Here $>>>$}

Pearson correlation coefficients indicate strong positive relationships between transactional, relational and ideological PCFg, moderate relationships with satisfaction, and small but significant relationships between PCFg and future behavioral intention (see Table 6).

\section{$<<<$ Insert Table 6 Here $>>>$}

A multiple regression was undertaken to analyze overall satisfaction and future behavioral intention based on PCFg (see Figure 2). Overall satisfaction was especially associated with transactional PCFg $(\beta=0.268, p<0.001)$ as most volunteers had lower expectations of transactional PC than the other two PC types, but they were comparatively highly satisfied with their experiences regarding transactional PC type. Therefore, the transactional PC gap score was larger compared to the other two PC types, and it appeared to have a greater influence on overall 
satisfaction. However, the variance explained in this model is not very substantial $\left(\mathrm{R}^{2}=0.174\right)$. That is, overall satisfaction was not highly influenced by the three PCFg scores.

\section{$<<<$ Insert Figure 2 Here $>>>$}

To test the RQ5, PC fulfilment based on satisfaction of experiences of PC types (PCFe) was examined using Pearson correlation coefficients. The three PCFe scores (i.e. transactional, relational and ideological) had a stronger and more positive relationship with overall satisfaction and future behavioral intention than three PCFg (see Table 7). Also, three PCFe were strongly related to each other. This result demonstrated that PCFe is strongly associated with overall satisfaction.

\section{$<<<$ Insert Table 7 Here $>>>$}

In addition, a multiple regression analysis showed that the three PCFe scores were significantly associated with overall satisfaction $\left(\mathrm{R}^{2}=0.509\right)$ (see Figure 3 ). Overall satisfaction was particularly related to relational PCFe $(\beta=0.361, p<0.001)$ and ideological PCFe $(\beta=0.261$, $p<0.001)$ as most volunteers in this study were more satisfied with their experiences of relational and ideological PCtypes than transactional PC. More than one third of the variance $\left(\mathrm{R}^{2}=0.391\right)$ in future behavioral intention was explained by the direct effect of overall satisfaction $(\beta=0.625, p<0.001)$.

\section{$<<<$ Insert Figure 3 Here $>>>$ DISCUSSION AND CONCLUSION}

This study found that ideological PC appeared to be a more important PC type than the two other PC types in terms of the expectations of volunteers, but that different motivations were related to different types of PC. The significant differences of experiences of PC types in relation to overall satisfaction and future behavioral intention were confirmed between motivation-based 
volunteer sub-groups. Overall satisfaction was positively related to and influenced by the three PCFe scores and overall satisfaction had a significant effect on future behavioral intention. The model based on experience scores (PCFe) provided better prediction of satisfaction than the model based on gap scores (PCFg). Based on the findings of this study, there are several theoretical and practical implications and contributions of this study. Research limitations and future research directions are also discussed.

\section{Theoretical Implications}

This finding in this study supported several previous research findings about PC and contributes to the body of literature. Though Nichols and Ojala (2009) based their findings of a sample of volunteers from a single sport event and collected data at one point in time, the current study addressed this limitation by collecting data from three different sport events and conducting both pre-event and post-event surveys. It is the first contribution of this study to result in increased generalizability of studies in relation to PC by extending the range of sport events investigated.

Second, the findings of this study supported those of Vantilborgh et al. $(2012,2014)$ who found that ideological PC was significantly related to increasing involvement of volunteers. Whereas Liao-Troth (2005) examined two PC types; transactional and relational, and Wang and Yu (2015) considered PC as a single concept, this study explored three possible PC types (i.e. transactional, relational and ideological contracts) and found that ideological PC seemed to be a more important type than the other two PC types.

Third, this study supported the finding of Wang and Yu (2015) that motivation was related to PC type. As this study classified sport event volunteers into four motivation-based subgroups, each volunteer sub-group that had different dominant motivations tended to expect and 
rank different PC types as the most important. For example, the sub-group of volunteers mostly motivated by extrinsic rewards preferred transactional PC rather than the other PC types as they tended to be motivated by tangible benefits. In contrast, volunteers who were motivated mostly by love of sport, community involvement and expression of values valued ideological PC more than the other PC types. Thus, the current study found empirical evidence that different motivations are associated with different types of PC which was not consistent with the finding of Liao-Troth's (2005) study that motives did not have a direct effect on PC types.

Fourth, Wang and $\mathrm{Yu}(2015)$ concluded that the concept of PC had a direct effect on volunteer satisfaction and sustained volunteerism. Based on their findings, this current study further developed the research questions regarding the impact of $\mathrm{PC}$ fulfilment on volunteer satisfaction and intention to continue volunteering. In this study, three PCFe scores were positively related to overall satisfaction. Furthermore, overall satisfaction was significantly related to future behavioral intention. Therefore, this finding was supportive of the previous study of Wang and Yu (2015) in terms of the prediction of volunteer satisfaction and sustained volunteerism linked to PC fulfilment.

Fifth, as operationalization and measurement of PC fulfilment was not clear in previous studies. The current study attempted to investigate the impact of PC fulfilment measured using two alternative perspectives; PCFg (based on the gap between expectations and experiences) and PCFe (based on experience scores). This study found that PCFe seemed to better explain the impact of PC fulfilment on volunteer satisfaction than PCFg. Therefore, this current study can contribute to the measurement and identification of PC fulfilment to explore the impact of PC fulfilment. 


\section{Practical Implications}

Several practical implications for volunteer management at sport events emerge from the findings of this study. First, most sport event volunteers placed more importance on ideological PC. Pursuing the mission, values, or principles of the organization and sport event appear to be more important than transactional and relational factors for sport event volunteers. Therefore, sport event organizers may consider providing an orientation program that clearly describes the values and purpose of the sport event and the contributions of volunteers from a more valuebased perspective.

Second, in this study, each motivation-based volunteer sub-group expressed a preference for a different PC type and was found to have a different level of satisfaction and intention to continue volunteering. To fulfil the various motives of different sport event volunteers, volunteer coordinators and event organizers may need to consider segmenting sport event volunteers to better cater to their differing motives. The segmentation approach may result in the development of more effective volunteer management strategies. Volunteer coordinators can allocate flexible and appropriate volunteering schedules and volunteer positions to better matched volunteers. In addition, sport event organizers can provide a well-organized training program based on the categorization of information and characteristics of volunteers. For example, in this study, younger volunteers were highly motivated by material benefits, career opportunities and work experiences. These volunteers might appreciate more opportunities to access training that will enhance their job prospects or have a volunteer position to work with professional staff in order to make contacts for their career. In contrast, mature-aged and retired volunteers were pleased to participate in volunteer work in order to express their enthusiasm for the sport event that they have enjoyed and have an opportunity to interact with others who feel the same. Such volunteers 
might enjoy social functions related to this specific sport with other volunteers or spectators who have similar interests. In this case, this volunteer group might prefer the volunteer position in an information booth, guest services or player services which allows them to interact with others. Therefore, to effectively manage sport event volunteers, grouping of volunteers might be required to more clearly deliver a volunteer experience which matches their motivation and PC preference.

Third, volunteers who were more satisfied with their experiences related to each PC type were likely to have higher level of overall satisfaction and future behavioral intention than volunteers who were comparatively less satisfied with their experiences related to each PC type. As PCFe was significantly associated with overall satisfaction and intention to continue volunteering, satisfaction of experiences of each PC type may be important to enhancing the level of overall satisfaction and intention to volunteer next year. Therefore, volunteer coordinators and managers need to organize meaningful volunteer activities that match volunteers' motive and PC preference. Given that most volunteers in this study tended to report higher scores on ideological PC and motives related to love of sport, community involvement and altruistic values, an emphasis of opportunities such as contributing to the success of sport events and the community, offering service for sports operation and helping others, would be useful. In addition, providing the corresponding reward and recognition such as thank you letters, tangible benefits, career-related or social benefits might be necessary to increase the satisfaction of volunteers.

\section{Research Limitations and Future Research Directions}

Several limitations were found in this study. First, this research was not able to collect data from all 578 volunteers included in the sampling frame. Though this study may have 
provided new empirical evidence regarding motivations, PC, satisfaction and future behavioral intention, the findings cannot make generalizations about the entire sport event volunteer population. In particular, 'material benefits seekers' and 'career and community-oriented people' accounted for relatively few volunteers. It is not clear whether this is because these groups are actually smaller in the volunteer population, or whether volunteers who were motivated in this way were less inclined to complete this survey. In this study, these groups tended to be dominated by single young females who were currently studying for a postsecondary qualification and appeared to be motivated to volunteer to enhance their employability. If they are studying full-time, they may have less free time, and less actual 'love of sport'. This may have reduced their motivation to participate in the study and complete the surveys. As they were highly motivated by tangible and career benefits, perhaps organizers could encourage their participation through material inducements, work-related experiences, resume development and industry contacts. To increase survey response rates, researchers may repeat reminder emails to non-respondents and provide incentives to respondents in the form of prizes by a lottery (Nulty, 2008). If future research is able to boost the response rate then the validity of the study findings will increase.

Second, this study extended the range of sport events investigated by collecting various samples from three different types of non-mega sport events. However, the findings might not be globally generalized as the sample for this research was limited to a specific geographical area. Therefore, future research should make an effort to investigate other cases in other circumstances in order to reduce bias resulting from survey in the specific area and to decrease the effects of a small sample size. For this way, future research can use these methods to explore other cases of sport events and eventually increase the generalizability of sport event volunteer studies. 
Third, other possible motivation items can be considered to explore various volunteers' motives. Although this study excluded the factors of personal growth and interpersonal contacts due to factor loading problems, these two factors might be important for other sport event volunteers or other kinds of volunteers. Future research might uncover other motivation factors amongst sport event volunteers.

Fourth, this research found little evidence of PC breach as respondents were in general satisfied with their experiences of PC types. This may also be a result of non-response bias if dissatisfied volunteers wished to disengage themselves from completing the survey. PC breach seems to be related to the reduced volunteer effort (Farmer \& Fedor, 1999; Starnes, 2007) and increased withdrawal intentions (Kim et al., 2009). Future research might investigate the consequence of the breach of PC types on volunteer satisfaction and intention to continue volunteering.

Finally, PC fulfilment was operationalized both as the gap between expectations and experiences and as the satisfaction of experiences of PC. Satisfaction of PC experiences was found to be a much stronger predictor of future behavioral intentions than PC fulfilment as a gap score. The stronger test statistic for satisfaction of experiences of PC can be explained in part by common-method variance. Both fulfilment measures collected data on both independent and dependent variables at the same time. However, the gap score was calculated as the difference between data collected on two separate occasions. Whereas the experience score (IV) and behavioral intention score (DV) were collected at the same time using the same survey instrument. While it is not possible to identify the amount of common method variance it was a factor which contributed to stronger results for the experience score over the gap score. 
This study provided important theoretical and practical implications of sport event volunteerism from the perspective of PC types and volunteer motivation. The findings can be used to inform sport event organizations and volunteer coordinators to better understand and manage volunteers with more effective volunteer management strategies. The efforts of organizers and managers to develop advanced strategies for volunteers may result in increased volunteer satisfaction and greater intention to volunteer for future events.

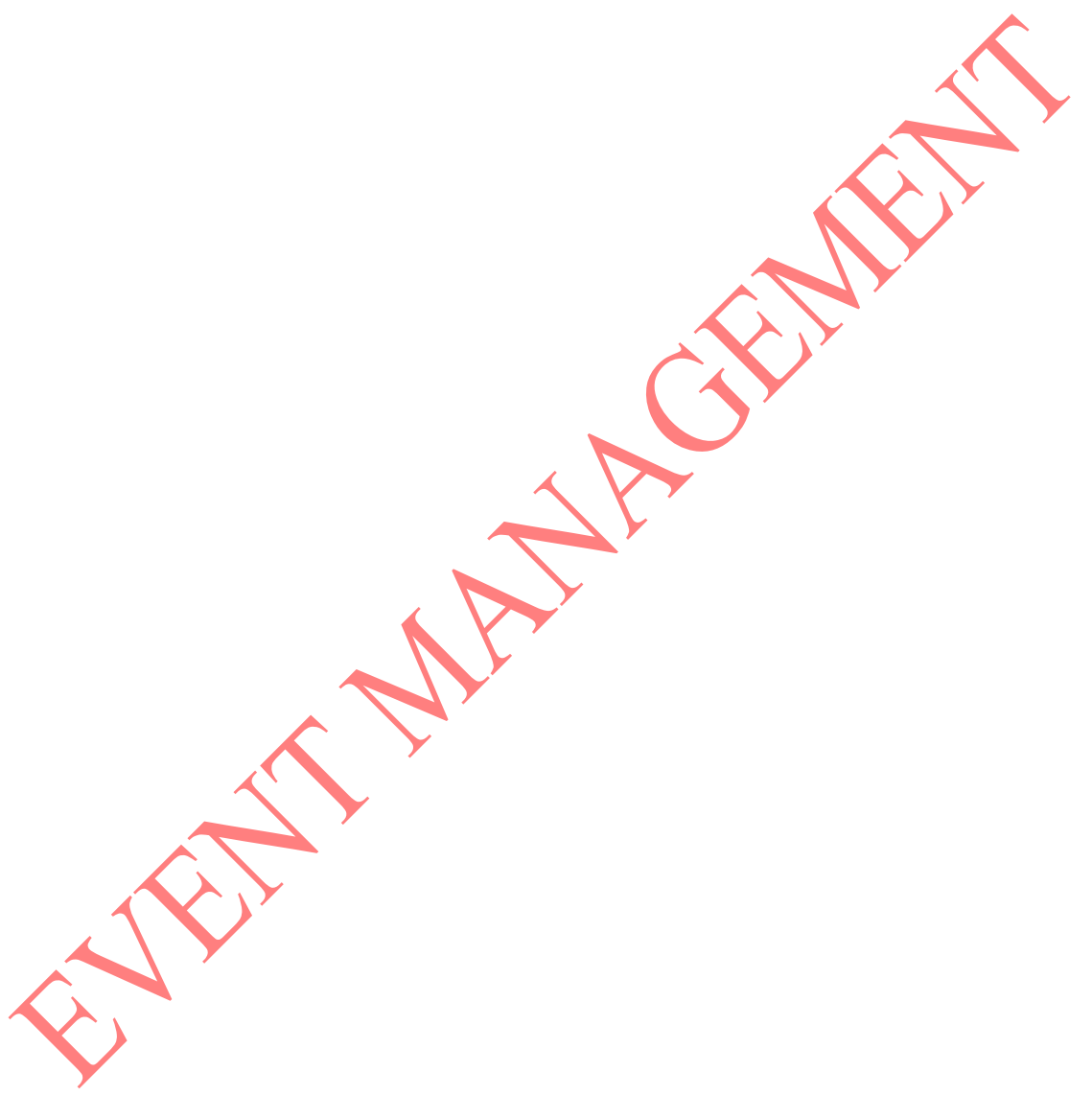




\section{REFERENCES}

Alexander, A., Kim, S. B., \& Kim, D. Y. (2015). Segmenting volunteers by motivation in the 2012 London Olympic Games. Tourism Management, 47(2015), 1-10.

Ali, A., Haq, I., Ramay, M., \& Azeem, M. (2010). The impact of psychological contract on affective commitment. Interdisciplinary Journal of Contemporary Research in Business, 2(7), 239-248.

Argyris, C. (1960). Understanding organizational behavior. Homewood, IL:Dorsey.

Bang, H., Won, D., \& Kim, Y. (2009). Motivations, commitment, and intentions to continue volunteering for sporting events. Event Management, 13(2), 69-81

Bunderson, J. S. (2001). How work ideologies shape the psychological contracts of professional employees: Doctors' responses to perceived breach. Journal of Organizational Behavior, 22(7), 717-741.

Bussell, H., \& Forbes, D. (2002). Understanding the volunteer market: The what, where, who and why of volunteering. International Journal of Non-profit and Voluntary Sector Marketing, 7, 244-257.

Clary, E. G., Snyder, M., Ridge, R. D., Copeland, J., Stukas, A. A., Haugen, J., \& Miene, P. (1998). Understanding and assessing the motivations of volunteers: a functional approach. Journal of personality and social psychology, 74(6), 1516-1530.

Conway, N., \& Briner, R. B. (2005). Understanding Psychological Contracts at Work: A Critical Evaluation of Theory and Research. Oxford: Oxford University Press.

Coyle-Shapiro, J., \& Kessler, I. (2003). The employment relationship in the UK public sector: A psychological contract perspective. Journal of Public Administration: Research and Theory, 13(2), 213-230. 
Dolnicar, S., \& Grün, B. (2008). Challenging “factor-cluster segmentation”. Journal of Travel Research, 47(1), 63-71.

Farmer, S. M., \& Fedor, D. B. (1999). Volunteer participation and withdrawal: A psychological contract perspective on the role of expectations and organizational support. Nonprofit Management \&Leadership, 9(4), 349-367.

Farrell, J. M., Johnston, M. E., \& Twynam, G. D. (1998). Volunteer motivation, satisfaction, and management at an elite sporting competition. Journal of Sport Management, 12(4), 288300.

Griep, Y., Vantilborgh, T., Baillien, E., \& Pepermans, R. (2016). The mitigating role of leadermember exchange when perceiving psychological contract violation: a diary survey study among volunteers. European Journal of Work and Organizational Psychology, 25(2), $254-271$.

Grimmer, M., \& Oddy, M. (2007). Violation of the psychological contract: The mediating effect of relational versus transactional beliefs. Australian Journal of Management, 32(1), 153174.

Harman, A., \& Doherty, A. (2017). Psychological contract fulfilment for volunteer youth sport coaches. International Journal of Sport Management and Marketing, 17(1-2), 94-120.

Holmes, K., \& Smith, K. (2009). Managing volunteers in tourism: Destinations, attractions and events. Wallingford: Elsevier Butterworth-Heinemann.

International Labor Organization. (2011). Manual on the measurement of volunteer work. Geneva: International Labor Office.

Karagonlar, G., Eisenberger, R., \& Aselage, J. (2016). Reciprocation wary employees discount psychological contract fulfillment. Journal of Organizational Behavior, 37(1), 23-40. 
Kim, E., Fredline, L., \& Cuskelly, G. (2018). Heterogeneity of sport event volunteer motivations: A segmentation approach. Tourism Management, 68(2018), 375-386.

Kim, M., Trail, G. T., Lim, J., \& Kim, Y. K. (2009). The role of psychological contract in intention to continue volunteering. Journal of Sport Management, 23(5), 549-573.

Kingshott, R., \& Pecotich, A. (2007). The impact of psychological contract on trust and commitment in supplier-distributor relationships. European Journal of Marketing, 41(9/10), 1053-1072.

Levinson, H. (1962). Men, management and mental health. Cambridge, MA.Harvard University Press.

Liao-Troth, M. A. (2005). Are they here for the long haul? The effects of functional motives and personality factors on the psychological contracts of volunteers. Nonprofit and Voluntary Sector Quarterly, 34(4), 510-530.

Low, C. H., Bordia, P., \& Bordia, S. (2016).What do employees want and why? An exploration of employees' preferred psychological contract elements across career stages. Human relations, $69(7), 1457-1481$

Lu, V. N., Capezio, A., Restubog, S. L. D., Garcia, P. R., \& Wang, L. (2016). In pursuit of service excellence: Investigating the role of psychological contracts and organizational identification of frontline hotel employees. Tourism Management, 56, 8-19.

Morrison, E. W., \& Robinson, S. L. (1997). When employees feel betrayed: A model of how psychological contract violation develops. Academy of Management Review, 22(1), 226256. 
Nichols, G., \& Ojala, E. (2009). Understanding the management of sports events volunteers through psychological contract theory. VOLUNTAS: International Journal of Voluntary and Nonprofit Organizations, 20(4), 369-387.

Nulty, D. D. (2008). The adequacy of response rates to online and paper surveys: what can be done?. Assessment \& evaluation in higher education, 33(3), 301-314.

Pauline, G., \& Pauline, J. S. (2009). Volunteer motivation and demographic influences at a professional tennis event. Team Performance Management, 15(3/4), 172-184.

Rayton, B. A., \& Yalabik, Z. Y. (2014). Work engagement, psychological contract breach and job satisfaction. The International Journal of Human Resource Management, 25(17), $2382-2400$.

Robinson, S. L. (1996). Trust and breach of the psychological contract. Administrative Science Quarterly, 41, 574-599.

Robinson, S. L., \& Rousseau, D. M. (1994) Violating the psychological contract: Not the exception but the norm. Journal of organizational behavior, 15(3), 245-259.

Rousseau, D. M. (1989). Psychological and implied contracts in organizations. Employee responsibilities and rights journal, 2(2), 121-139.

Rousseau, D. M. (1990). New hire perceptions of their own and their employer's obligations: A study of psychological contracts. Journal of organizational Behavior, 11(5), 389-400.

Rousseau, D. M. (1995). Psychological Contracts in Organizations: Understanding Written and Unwritten Agreements. Thousand Oaks, CA: Sage.

Schein, E. H. (1980). Organizational psychology. Englewood Cliffs, NJ: Prentice Hall. Schlesinger, T., \& Gubler, R. (2016). Motivational profiles of sporting event volunteers. Sport in Society, 19(10), 1-21. 
Starnes, B. J. (2007). An analysis of psychological contracts in volunteerism and the effect of contract breach on volunteer contributions to the organization. The International Journal of Volunteer Administration, 24(3), 31-41.

Taylor, T., Darcy, S., Hoye, R., \& Cuskelly, G. (2006). Using psychological contract theory to explore issues in effective volunteer management. European Sport Management Quarterly, 6(2), 123-147.

Thompson, J. A., \& Bunderson, J. S. (2003). Violations of principle: Ideological currency in the psychological contract. Academy of Management Review, 28(4), 571-586.

Vantilborgh, T. (2015). Volunteers' reactions to psychological contract fulfillment in terms of exit, voice, loyalty, and neglect behavior. VOLUNTAS. International Journal of Voluntary and Nonprofit Organizations, 26(2), 604-628.

Vantilborgh, T., Bidee, J., Pepermans, R., Willems, J., Huybrechts, G., \& Jegers, M. (2012). Volunteers' psychological contracts; Extending traditional views. Nonprofit and Voluntary Sector Quarterly, 4 1(6), 1072-1091.

Vantilborgh, T., Bidee, J., Pepermans, R., Willems, J., Huybrechts, G., \& Jegers, M. (2013). Revisiting the relationship between personality and psychological contracts: a moderated mediation model explaining volunteer performance. Social Service Review, 87(1), 158186.

Vantilborgh, T., Bidee, J., Pepermans, R., Willems, J., Huybrechts, G., \& Jegers, M. (2014). Effects of ideological and relational psychological contract breach and fulfilment on volunteers' work effort. European Journal of Work and Organizational Psychology, 23(2), 217-230. 
Walker, A., Accadia, R., \& Costa, B. M. (2016). Volunteer retention: The importance of organisational support and psychological contract breach. Journal of Community Psychology, 44(8), 1059-1069.

Wang, C., \& Yu, L. (2015). Managing student volunteers for mega events: motivation and psychological contract as predictors of sustained volunteerism. Asia Pacific Journal of Tourism Research, 20(3), 338-357.

Withey, M. J., \& Cooper, W. H. (1989). Predicting exit, voice, loyalty, and neglect. Administrative Science Quarterly, 34, 521-539. 
Table 1

Operational definition of variables

\begin{tabular}{|c|c|c|c|}
\hline \multicolumn{2}{|c|}{ Variable } & Operational definition & Measurement \\
\hline \multicolumn{2}{|c|}{$\begin{array}{l}\text { Socio-demographic } \\
\text { characteristic }\end{array}$} & $\begin{array}{l}\text { A group defined by its sociological and } \\
\text { demographic characteristics }\end{array}$ & $\begin{array}{l}\text { Gender, age, marital status, } \\
\text { employment status and educational } \\
\text { level }\end{array}$ \\
\hline \multicolumn{2}{|c|}{ Volunteer motivation } & Reasons for volunteering at sport events & $\begin{array}{l}\text { 5-point Likert scale }(1=\text { not } \\
\text { important, } 5=\text { extremely important })\end{array}$ \\
\hline \multirow{3}{*}{$\begin{array}{l}\text { Expectation/ } \\
\text { Experience }\end{array}$} & $\begin{array}{c}\text { Transactional } \\
\text { PC }\end{array}$ & $\begin{array}{l}\text { Volunteers (expect to feel/felt) as though } \\
\text { they (will be/were) treated fairly by the } \\
\text { event organizers and to get something in } \\
\text { return for their time and effort }\end{array}$ & \multirow{3}{*}{$\begin{array}{l}5 \text {-point Likert scale }(1=\text { not } \\
\text { important, } 5=\text { extremely important }) / \\
5 \text {-point Likert scale }(1=\text { very } \\
\text { dissatisfied, } 5=\text { very satisfied })\end{array}$} \\
\hline & $\begin{array}{l}\text { Relational } \\
\text { PC }\end{array}$ & $\begin{array}{l}\text { Volunteers (expect to feel/felt) as though } \\
\text { they (will be/were) well integrated with the } \\
\text { event organization and (have/had) a good } \\
\text { relationship with staff and managers }\end{array}$ & \\
\hline & $\begin{array}{l}\text { Ideological } \\
\text { PC }\end{array}$ & $\begin{array}{l}\text { Volunteers (expect to feel/felt) as though } \\
\text { the event organizers (have/had) similar } \\
\text { values to volunteers and they (will be } \\
\text { working/worked) to achieve the same } \\
\text { goals for the event }\end{array}$ & \\
\hline \multicolumn{2}{|c|}{ Ranking of three PC types } & $\begin{array}{l}\text { To rank three statements regarding } \\
\text { expectations of three PC types }\end{array}$ & $\begin{array}{l}\text { From the most important (1) } \\
\text { to the least important (3) }\end{array}$ \\
\hline \multicolumn{2}{|c|}{ Gap of three PC types } & $\begin{array}{l}\text { 1) Expectation of } \mathrm{PC}>\text { Experience of } \mathrm{PC} \text { : } \\
\mathrm{PC} \text { breach measured by gap } \\
\text { 2) Expectation of } \mathrm{PC} \leq \text { Experience of } \mathrm{PC} \text { : } \\
\mathrm{PC} \text { fulfilment measured by gap }\end{array}$ & $\begin{array}{l}\text { To subtract the mean of } \\
\text { expectations of } \\
\text { (transactional/relational/ } \\
\text { ideological) PC from the mean of } \\
\text { experiences of (transactional/ } \\
\text { relational/ideological) PC }\end{array}$ \\
\hline \multicolumn{2}{|c|}{ Overall satisfaction } & $\begin{array}{l}\text { Based on their volunteer experiences, } \\
\text { overall, volunteers are satisfied with } \\
\text { working in the event organization }\end{array}$ & $\begin{array}{l}\text { 5-point Likert scale }(1=\text { very } \\
\text { dissatisfied, } 5=\text { very satisfied })\end{array}$ \\
\hline \multicolumn{2}{|c|}{$\begin{array}{l}\text { Intention to continue } \\
\text { volunteering }\end{array}$} & $\begin{array}{l}\text { Gikelihood that a volunteer would } \\
\text { volunteer at the sport event next year }\end{array}$ & $\begin{array}{l}5 \text {-point Likert scale }(1=\text { strongly } \\
\text { disagree, } 5=\text { strongly agree })\end{array}$ \\
\hline
\end{tabular}


Table 2

Hierarchical cluster analysis on standardized motivation variables and socio-demographic characteristics between four volunteer sub-groups $(n=261)$

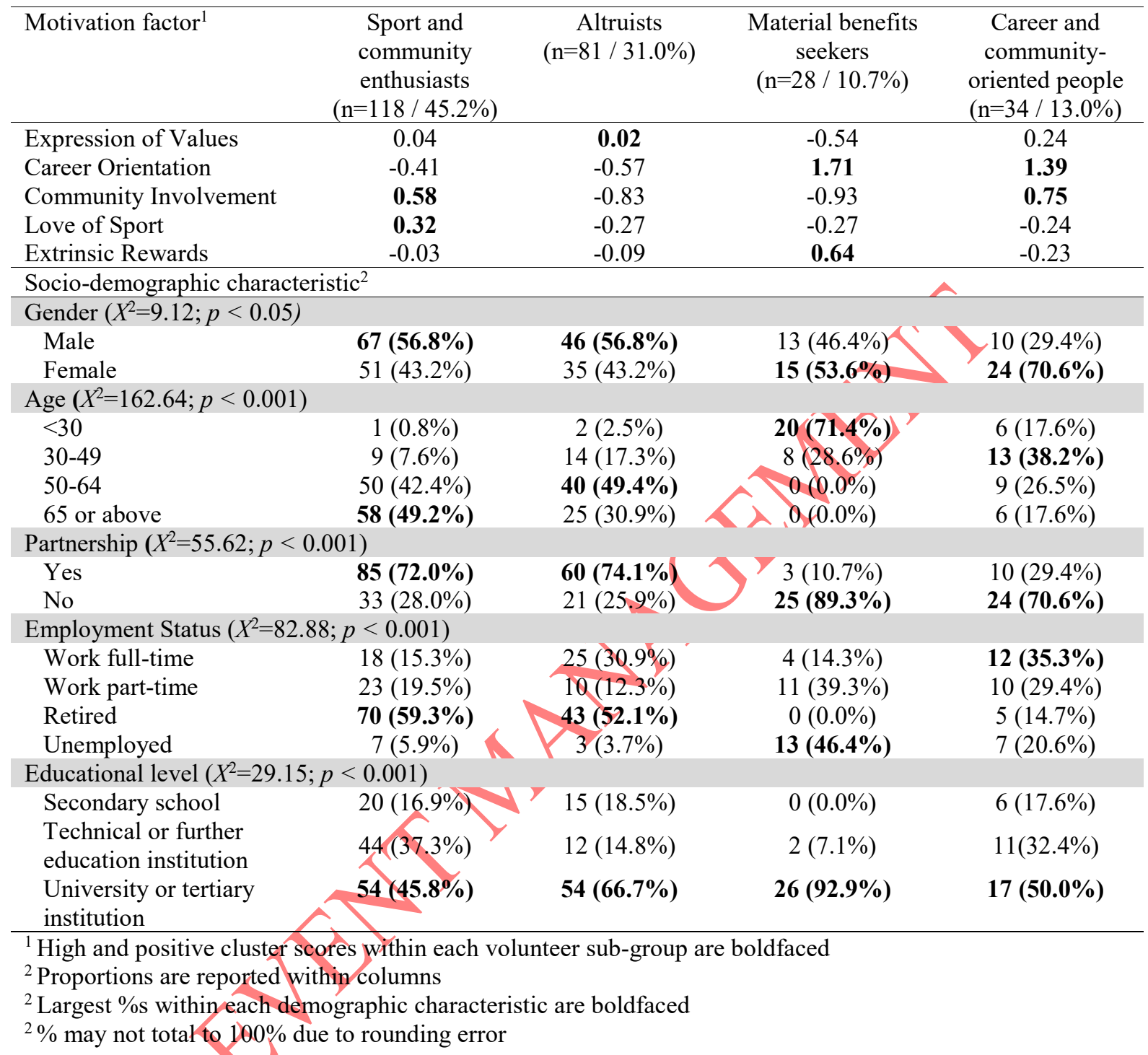


Table 3

Differences for expectation and ranking of PC types between four volunteer sub-groups $(\mathrm{n}=261)$

\begin{tabular}{|c|c|c|c|c|c|c|c|c|c|c|c|}
\hline \multirow[b]{2}{*}{ Expectation $^{1}$} & \multicolumn{2}{|c|}{$\begin{array}{c}\text { Total } \\
\text { Sample } \\
(\mathrm{n}=261 / \\
100 \%)\end{array}$} & \multicolumn{2}{|c|}{$\begin{array}{c}\mathrm{a} \\
\text { Sport and } \\
\text { community } \\
\text { enthusiasts } \\
(\mathrm{n}=118 / 45.2 \%)\end{array}$} & \multicolumn{2}{|c|}{$\begin{array}{c}\mathrm{b} \\
\text { Altruists } \\
(\mathrm{n}=81 / 31.0 \%)\end{array}$} & \multicolumn{2}{|c|}{$\begin{array}{c}c \\
\text { Material } \\
\text { benefits seekers } \\
(n=28 / 10.7 \%)\end{array}$} & \multicolumn{2}{|c|}{$\begin{array}{c}\mathrm{d} \\
\text { Career and } \\
\text { community- } \\
\text { oriented people } \\
(\mathrm{n}=34 / 13.0 \%)\end{array}$} & \multirow[b]{2}{*}{ ANOVA } \\
\hline & $\mathrm{M}$ & SD & $\mathrm{M}$ & $\mathrm{SD}$ & $\mathrm{M}$ & SD & $\mathrm{M}$ & SD & $\mathrm{M}$ & $\mathrm{SD}$ & \\
\hline Transactional & 3.20 & 1.09 & 3.21 & 1.07 & $2.86_{\mathrm{c}, \mathrm{d}}$ & 1.05 & $3.61_{b}$ & 0.79 & $3.59_{b}$ & 1.23 & $\begin{array}{l}F=5.623 ; \\
p<0.017\end{array}$ \\
\hline Relational & 3.43 & 1.05 & 3.50 & 1.04 & $3.19_{\mathrm{d}}$ & 1.03 & $3.14_{d}$ & 1.01 & $4.00_{b, c}$ & 0.95 & $\begin{array}{l}F=5.980 \\
p<0.017\end{array}$ \\
\hline Ideological & 3.70 & 0.99 & 3.80 & 0.98 & 3.48d & 0.99 & $3.39_{\mathrm{d}}$ & 0.92 & $4.12 \mathrm{~b}, \mathrm{c}$ & 0.95 & $\begin{array}{l}F=4.762 \\
p<0.017\end{array}$ \\
\hline \multicolumn{12}{|c|}{$\%$ Ranked most important ${ }^{2}$} \\
\hline Transactional & \multicolumn{2}{|c|}{$33.0 \%$} & \multicolumn{2}{|c|}{$33.1 \%$} & \multicolumn{2}{|c|}{$23.5 \%$} & \multicolumn{2}{|c|}{$64.3 \%$} & & & \multirow{3}{*}{ - } \\
\hline Relational & \multicolumn{2}{|c|}{$22.6 \%$} & \multirow{2}{*}{\multicolumn{2}{|c|}{$23.7 \%$}} & \multicolumn{2}{|c|}{$23.5 \%$} & & & & & \\
\hline Ideological & \multicolumn{2}{|c|}{$44.4 \%$} & & $\%$ & \multicolumn{2}{|c|}{$53.1 \%$} & & & \multicolumn{2}{|c|}{$47.1 \%$} & \\
\hline
\end{tabular}

Subscripts to the mean scores denote significant differences $(\alpha=0.017,0.05 / 3)$ identified using Scheffe post-hoc tests Highest cluster scores within each volunteer sub-group are boldfaced

${ }^{1}$ Based on mean value on a 5 -point Likert scale $(1=$ not important, $2=$ slightly important, $3=$ somewhat important, $4=$ very important, $5=$ extremely important)

$2 \%$ may not total to $100 \%$ due to rounding error 
Table 4

Differences for experience of PC types, overall satisfaction, and future behavioral intention between four volunteer sub-groups $(n=261)$

\begin{tabular}{|c|c|c|c|c|c|c|c|c|c|c|c|}
\hline & \multicolumn{2}{|c|}{$\begin{array}{c}\text { Total } \\
\text { Sample } \\
(\mathrm{n}=261 / \\
100 \%)\end{array}$} & \multicolumn{2}{|c|}{$\begin{array}{c}\mathrm{a} \\
\text { Sport and } \\
\text { community } \\
\text { enthusiasts } \\
(\mathrm{n}=118 / 45.2 \%)\end{array}$} & \multicolumn{2}{|c|}{$\begin{array}{c}\mathrm{b} \\
\text { Altruists } \\
(\mathrm{n}=81 / 31.0 \%)\end{array}$} & \multicolumn{2}{|c|}{$\begin{array}{c}c \\
\text { Material } \\
\text { benefits seekers } \\
(n=28 / 10.7 \%)\end{array}$} & \multicolumn{2}{|c|}{$\begin{array}{c}\mathrm{d} \\
\text { Career and } \\
\text { community- } \\
\text { oriented people } \\
(\mathrm{n}=34 / 13.0 \%)\end{array}$} & \multirow[b]{2}{*}{ ANOVA } \\
\hline & $\mathrm{M}$ & $\mathrm{SD}$ & M & SD & $\mathrm{M}$ & SD & M & SD & $\mathrm{M}$ & $\mathrm{SD}$ & \\
\hline \multicolumn{12}{|l|}{ Experience $^{1,3}$} \\
\hline Transactional & 3.94 & 0.85 & 4.03 & 0.88 & $3.78_{\mathrm{d}}$ & 0.82 & $3.68_{d}$ & 0.77 & $4.26_{b, c}$ & 0.71 & $\begin{array}{l}F=4.094 ; \\
p<0.017\end{array}$ \\
\hline Relational & 3.95 & 0.87 & $4.05_{\mathrm{c}}$ & 0.90 & $3.83_{\mathrm{d}}$ & 0.82 & $3.39_{\mathrm{a}, \mathrm{d}}$ & 0.83 & & 0.65 & $\begin{array}{l}F=7.842 \\
p<0.017\end{array}$ \\
\hline Ideological & 4.11 & 0.77 & $4.17_{\mathrm{c}}$ & 0.87 & $3.96_{\mathrm{d}}$ & 0.68 & $3.79_{\mathrm{a}, \mathrm{d}}$ & 0.50 & $4.50_{b, e}$ & 0.56 & $\begin{array}{l}F=6.172 ; \\
p<0.017\end{array}$ \\
\hline $\begin{array}{l}\text { Overall } \\
\text { satisfaction }^{2,3}\end{array}$ & 4.07 & 0.83 & $4.19_{c}$ & 0.81 & $3.94_{d}$ & 0.81 & $3.54_{\mathrm{a}, \mathrm{d}}$ & & $4.38_{b, c}$ & 0.70 & $\begin{array}{l}F=7.594 ; \\
p<0.025\end{array}$ \\
\hline $\begin{array}{l}\text { Future } \\
\text { behavioral } \\
\text { intention }^{2,4}\end{array}$ & 3.88 & 1.02 & $4.15_{b, c}$ & 0.92 & $3.59_{\mathrm{a}, \mathrm{d}}$ & 1.06 & & 0.85 & $4.24_{b, c}$ & 0.89 & $\begin{array}{c}F=12.780 \\
p<0.025\end{array}$ \\
\hline \multicolumn{12}{|c|}{$\begin{array}{l}\text { Highest cluster scores across four volunteer sub-groups are boldfaced } \\
{ }^{1} \text { Subscripts to the mean scores denote significant differences }(\alpha=0.017,0.05 / 3) \text { identified using Scheffe post-hoc tests } \\
{ }^{2} \text { Subscripts to the mean scores denote significant differences }(\alpha=0.025,0.05 / 2) \text { identified using Scheffe post-hoc tests } \\
{ }^{3} \text { Based on mean value on a } 5 \text {-point Likert scale }(1=\text { very dissatisfied, } 2=\text { dissatisfied, } 3=\text { neither, } 4=\text { satisfied, } 5=\text { very } \\
\text { satisfied) } \\
{ }^{4} \text { Based on mean value on a 5-point Likert scale ( } 1=\text { strongly disagree, } 2=\text { disagree, } 3=\text { neither, } 4=\text { agree, } 5=\text { strongly } \\
\text { agree) }\end{array}$} \\
\hline
\end{tabular}


Table 5

Comparing gap scores between expectations and experiences of PC types $(n=261)$

\begin{tabular}{|c|c|c|c|c|}
\hline $\operatorname{Gap}^{1}$ & & $\begin{array}{c}\text { Transactional } \\
\% \text { fulfilled } 86.2 \\
\% \text { breached } 13.8\end{array}$ & $\begin{array}{c}\text { Relational } \\
\% \text { fulfilled } 86.6 \\
\% \text { breached } 13.4\end{array}$ & $\begin{array}{c}\text { Ideological } \\
\% \text { fulfilled } 83.5 \\
\% \text { breached } 16.5\end{array}$ \\
\hline $\begin{array}{l}\text { Total Sample } \\
(n=261 / 100 \%)\end{array}$ & $\begin{array}{c}\text { M } \\
\text { SD } \\
\text { Paired t-test }\end{array}$ & $\begin{array}{c}\mathbf{0 . 7 5} \\
1.39 \\
t=8.710 ; p<0.017\end{array}$ & $\begin{array}{c}0.52 \\
1.11 \\
t=7.575 ; p<0.017\end{array}$ & $\begin{array}{c}0.41 \\
1.09 \\
t=6.074 ; p<0.017\end{array}$ \\
\hline
\end{tabular}

Conservative alpha level used $(\alpha=0.017,0.05 / 3)$

Highest cluster score across three PC types is boldfaced

${ }^{1}$ Difference in mean scores between expectations and experiences

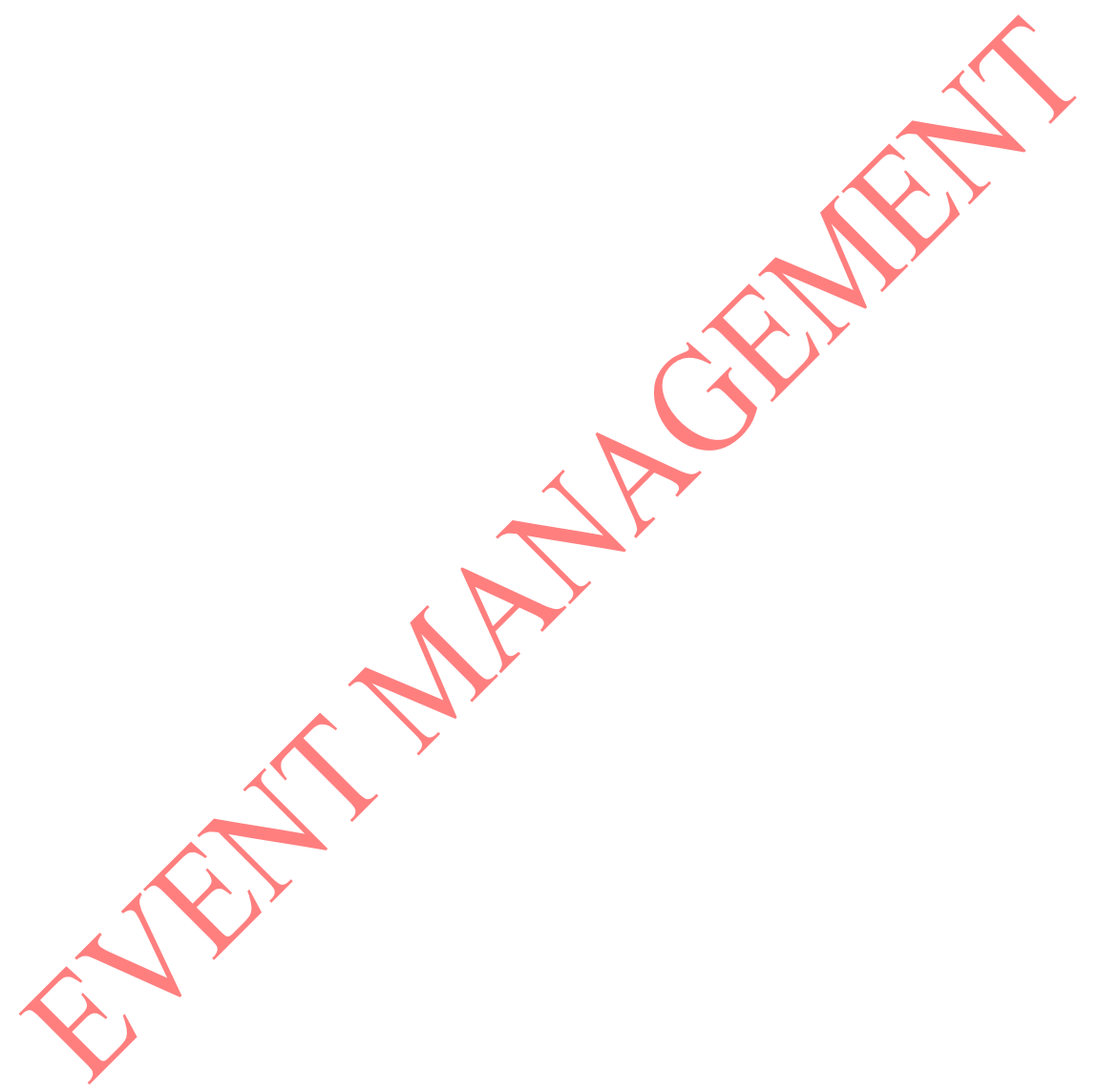


Table 6

Correlation between PCFg, overall satisfaction, and future behavioral intention $(\mathrm{n}=261)$

\begin{tabular}{|c|c|c|c|c|c|}
\hline Variable & 1 & 2 & 3 & 4 & 5 \\
\hline 1. Transactional PCFg & - & & & & \\
\hline 2. Relational PCFg & $0.598 * *$ & - & & & \\
\hline 3. Ideological PCFg & $0.560 * *$ & $0.743 * *$ & - & & \\
\hline 4. Overall satisfaction & $0.387 * *$ & $0.357 * *$ & $0.300 * *$ & - & \\
\hline 5. Future behavioral intention & $0.270 * *$ & $0.164 * *$ & $0.186^{* *}$ & $0.625 * *$ & - \\
\hline
\end{tabular}

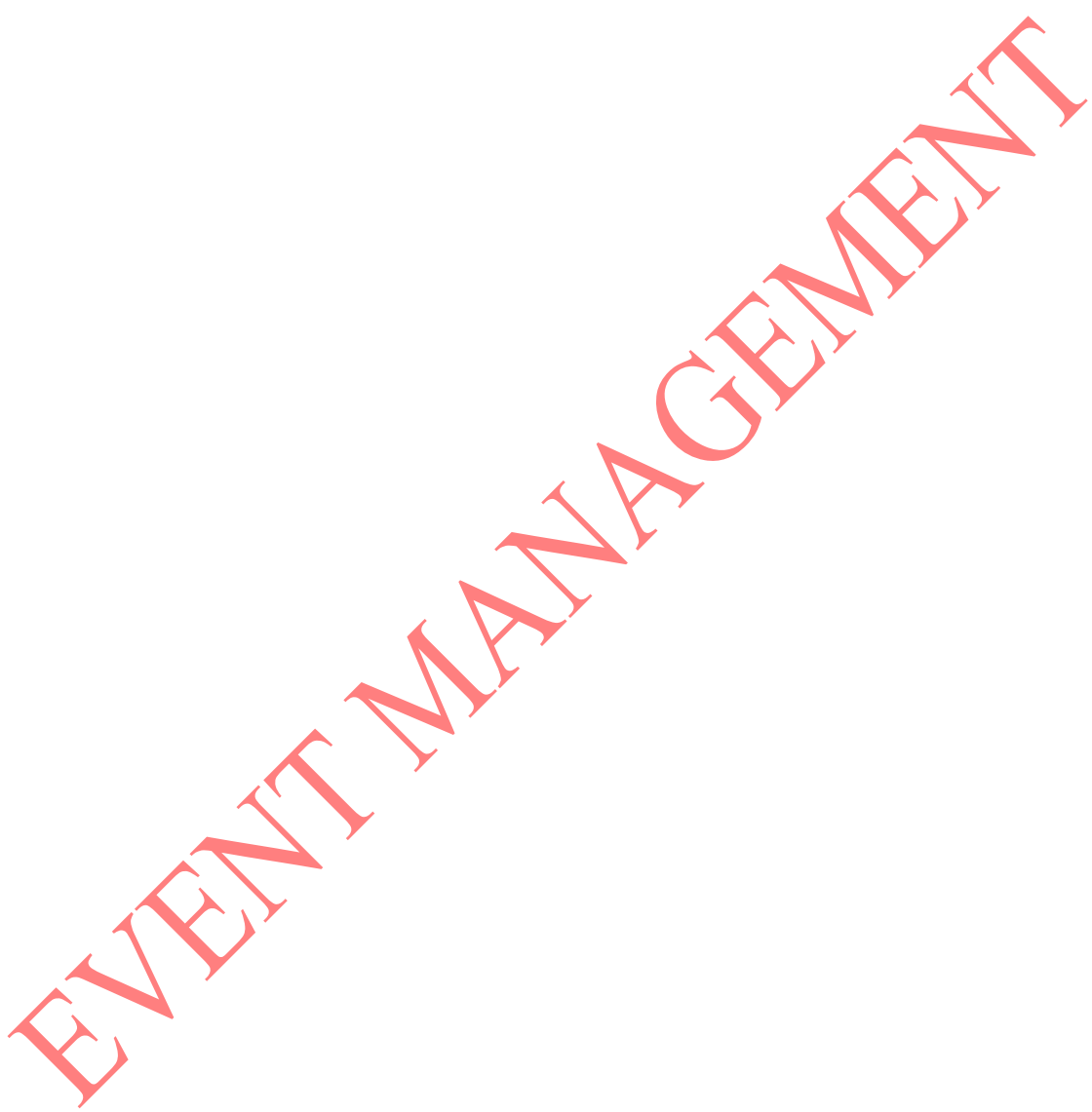


Table 7:

Correlation between PCFe, overall satisfaction, and future behavioral intention $(n=261)$

\begin{tabular}{|c|c|c|c|c|c|}
\hline Variable & 1 & 2 & 3 & 4 & 5 \\
\hline 1. Transactional PCFe & - & & & & \\
\hline 2. Relational PCFe & $0.730 * *$ & - & & & \\
\hline 3. Ideological PCFe & $0.750 * *$ & $0.766 * *$ & - & & \\
\hline 4. Overall satisfaction & $0.614 * *$ & $0.674 * *$ & $0.653 * *$ & - & \\
\hline 5. Future behavioral intention & $0.434 * *$ & $0.495 * *$ & $0.460 * *$ & $0.625 * *$ & - \\
\hline
\end{tabular}

** Correlation is significant at the 0.01 level (2-tailed)

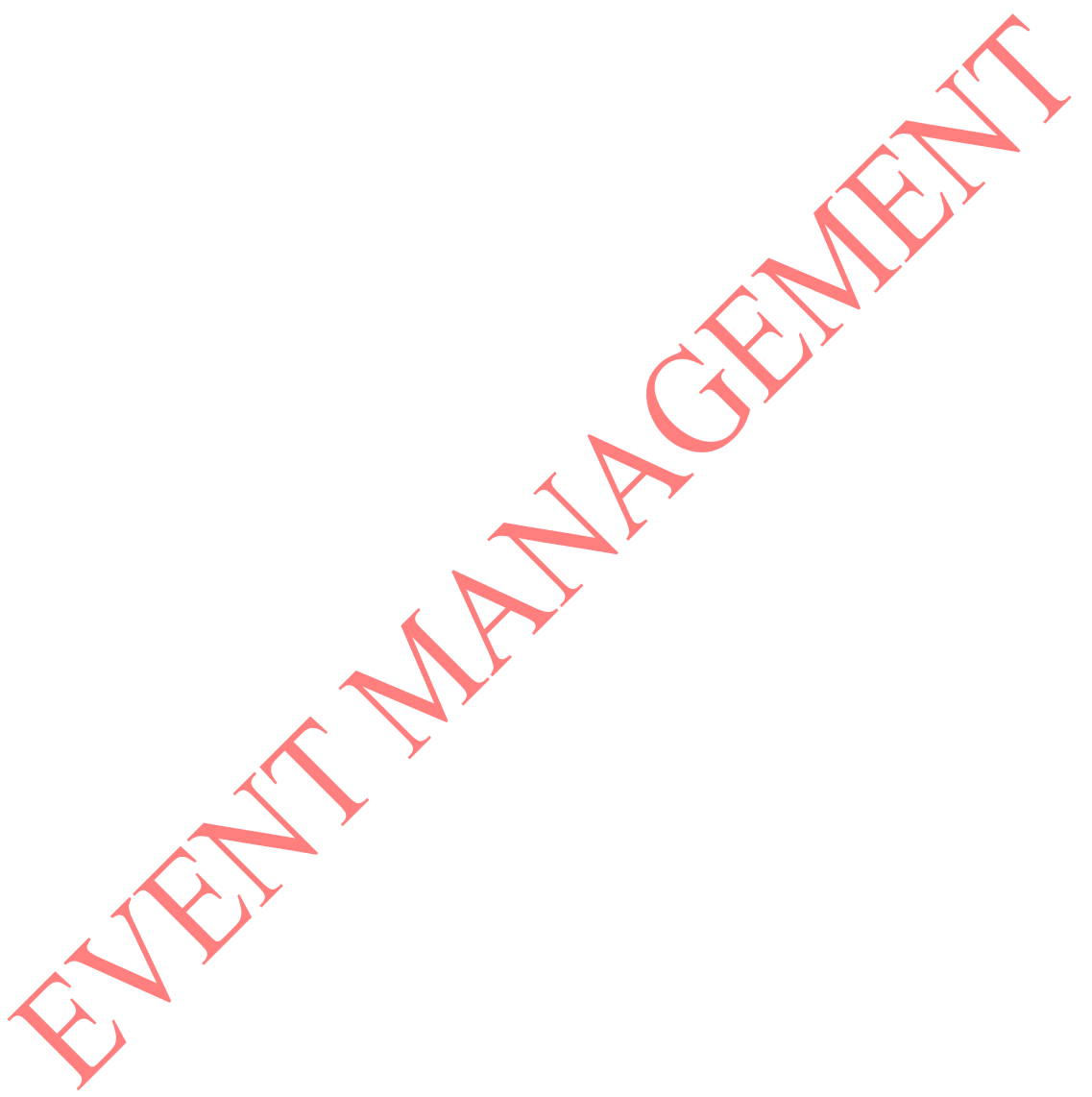




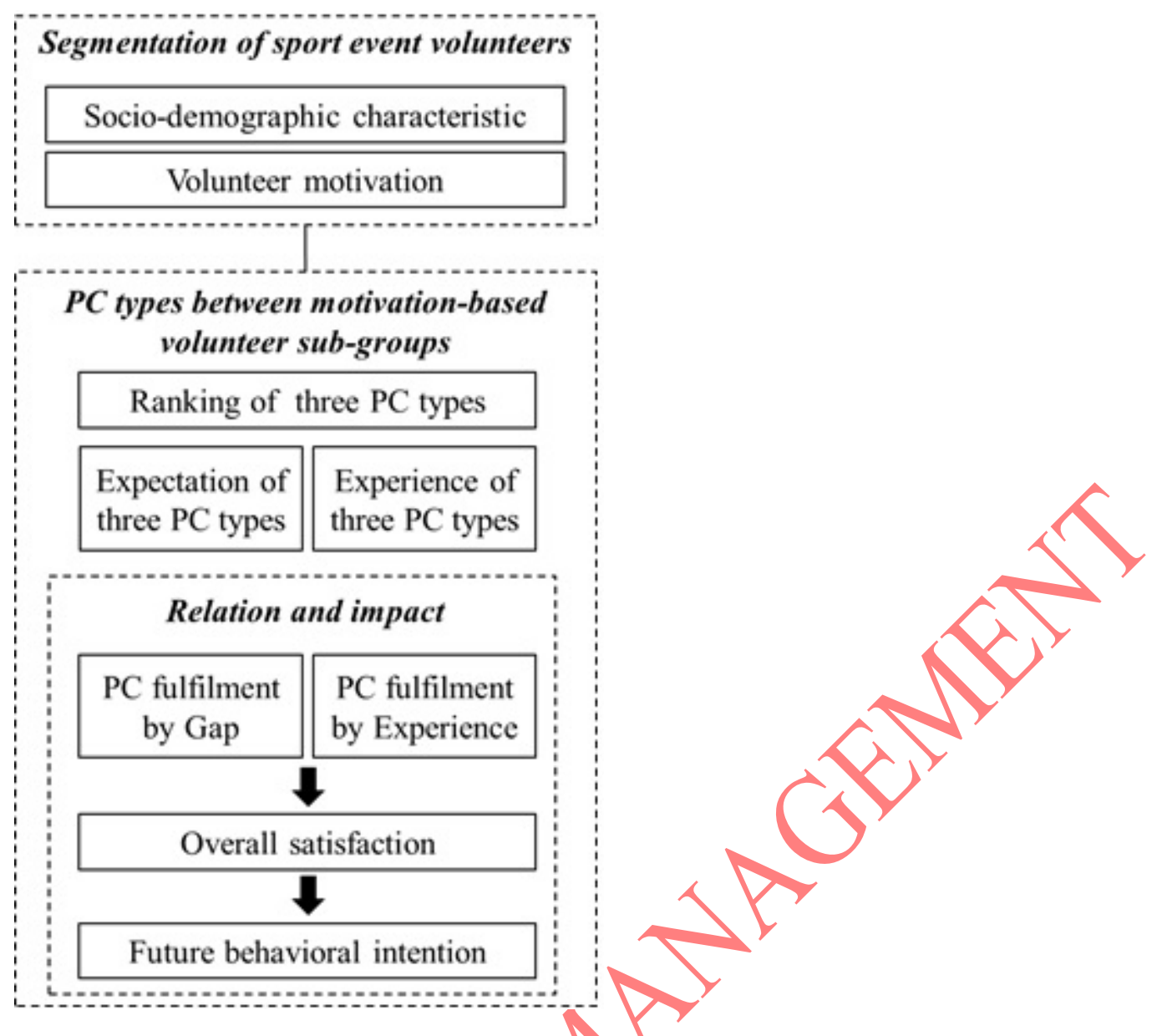

Figure 1: Conceptual framework

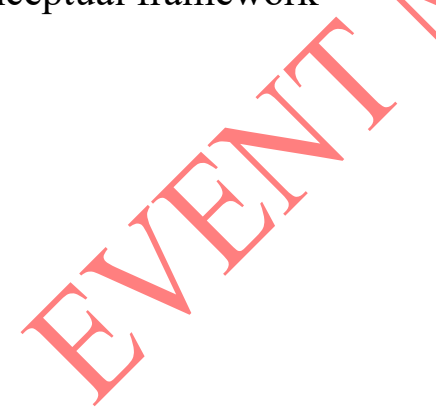




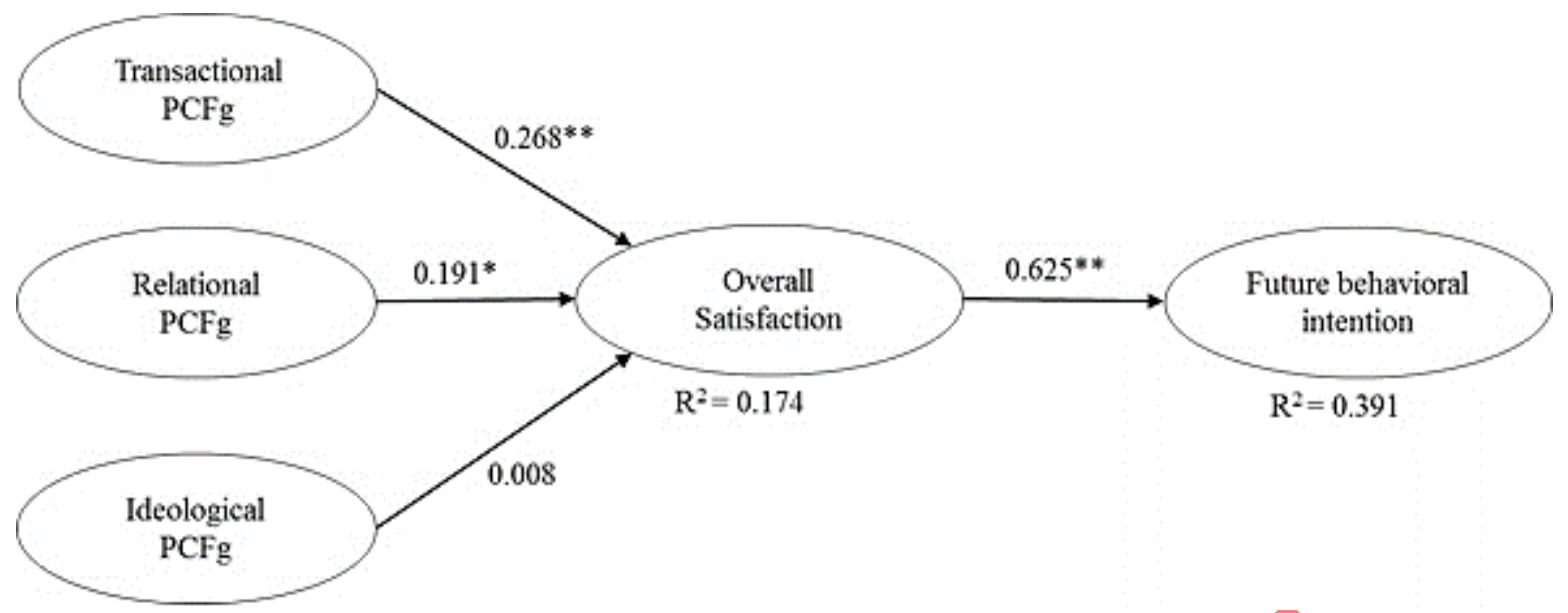

Figure 2: Regression analysis results of PCFg $(n=261)$

Figures indicate standardized beta coefficients

** Significant $p<0.001$

$*$ Significant $p<0.05$ 


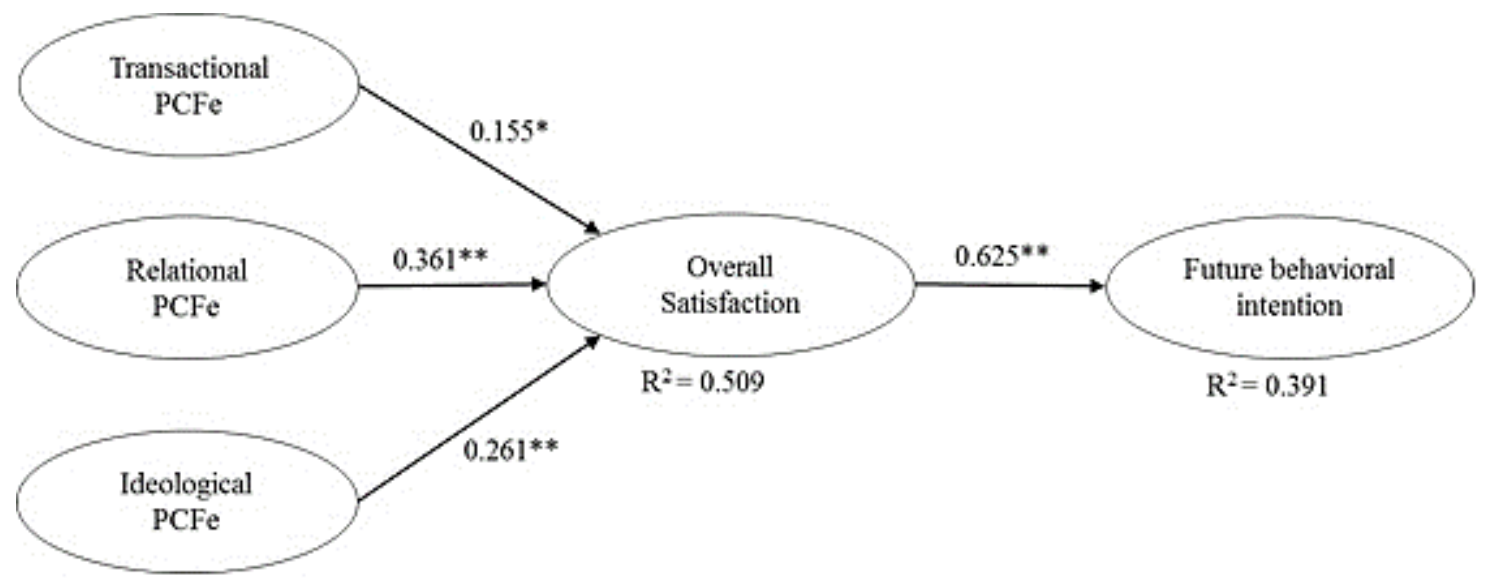

Figure 3: Regression analysis results of PCFe $(n=261)$

Figures indicate standardized beta coefficients

** Significant $p<0.001$

* Significant $p<0.05$ 